Our Nature (2012) 10: 24-33

\title{
Population Status Studies and Anthropogenic Impact on Birds of Biratnagar Sub-Metropolis
}

\author{
Kanchan Jha and Bharat Raj Subba \\ Department of Zoology \\ Post Graduate Campus (T.U.) Biratnagar \\ Emai:kanchanjha48@yahoo.com
}

\begin{abstract}
Birds have always fascinated man by their exquisite coloration. They have their functional role in the ecosystem as potential pollinators and scavengers, indeed rightly called bioindicators. Nepal being a mega diversity centre harbors more than 873 species of birds which amounts to $10 \%$ of the world. Recently with increase consciousness for biodiversity census and monitoring, many new species have been added to the list. The subtropical climate and greenery of Biratnagar submetropolis provide good habitat for several bird species but in the past three decades drastic changes have taken place in the environment of this place because of anthropogenic activities and climate change. Several commonly visible birds' species have left to turn out. Habitats of birds have shrunk here in such a way that very limited species of birds have become successful to show their representatives in this situation. Considering gradual loss of habitats because of increasing anthropogenic impacts and climate change, an attempt was made to study the present bird status of Biratnagar- sub metropolis. In twelve months of regular observation, eighty-one species of birds belonging to thirty-three families were recorded. Frequency of bird was counted by line transect method. The main five sites Tintolia- Balwahi (Latitude $26^{\circ} 26^{\prime} 32.4^{\prime \prime} \mathrm{N}$ and Longitude $087^{\circ} 18^{\prime} 09.4^{\prime \prime E}$ ), Baijnathpur, Ginaghat (Latitude $26^{0} 29^{\prime} 59.8^{\prime \prime} \mathrm{N}$ and Longitude 087 17 '53.2”E)”, Keshaliyakhola (Latitude $26^{\circ} 27^{\prime} 00^{\prime \prime} \mathrm{N}$ and Longitude $087^{\circ} 14.4^{\prime} 48.5^{\prime} \mathrm{E}$ ), Dudhfarm (Latitude $26^{0} 29^{\prime} 57.6^{\prime \prime} \mathrm{N}$ and Longitude $087^{\circ} 16^{\prime} 44.5^{\prime \prime} \mathrm{E}$ ) and Old airport (Latitude $26^{\circ} 25^{\prime} 40.8$ 'N Longitude $087^{\circ} 16^{\prime} 34.3$ 'E) were selected for study. On the basis of feeding habit birds recorded were carnivore $28.38 \%$, omnivore $14.80 \%$, insectivore $40.72 \%$, fructivore $3.70 \%$, grainivore $11.70 \%$ and nectivore $1.23 \%$. The Shannon Wiener diversity index in summer and winter were found to be 3.68361 and 4.1328 respectively. The recorded birds were common $59.23 \%$, fairly common $28.38 \%$ and $12.34 \%$ uncommon. The main causes of declining bird population in Biratnagar were found to have been anthropogenic impacts such as encroachment of habitats and feeding and breeding areas, use of insecticides, change in land use pattern, urbanization, poaching and effect of climate change.
\end{abstract}

Key words: Population status, anthropogenic impact, birds, Biratnagar

\section{Introduction}

Nepal is rich in bird diversity and considered as the paradise for birds.Nepal one of the most beautiful countries of the world. With the varied climatic zones, vegetation and landscapes, Nepal proves habitats to several species of birds. Though more works have been accomplished in birds but still there are many unexplored places in the country for the study of birds.Once Charkoshe Jhadi also was really rich in peafowl population. Those big Bombax ceiba nested by vulture and many big birds never failed to attract passersby. Those by gone days never come back but safe places for birds can be created. The present study is focused on the present 
Kanchan Jha and Bharat Raj Subba / Our Nature (2012) 10: 24-33

status and anthropogenic impacts on bird of Biratnagar. Several ornithologists have contributed to the bird of Nepal. The contribution of Flemming et al.(1984), Friensen et al.(1995), Subba (1995,1997,2001 and 2004), Fernandez et al.(2000),Stevenson et al.(2000), Marzluff et al.(2001), Shrestha (2001), Baral and Inskipp (2001), Sparks et al.(2002), Baral and Inskipp (2004), Surana et al.(2007), Jha and Subba(2011 and 2012) bear special mention.

\section{Materials and methods}

The present research is the outcome of twelve months (Oct 2010-oct 2o11) regular observations.First of all potential sites Tintolia- Balwahi (Latitude 26 26'32.4"N and Longitude $\left.087^{\circ} 18^{\prime} 09.4^{\prime \prime E}\right)$, Baijnathpur, Ginaghat (Latitude 26 $29^{\circ} 59.8^{\prime \prime} \mathrm{N}$ and Longitude $087^{0} 17^{\prime} 53.2$ 'E)", Keshaliyakhola (Latitude $26^{\circ} 27^{\prime} 00^{\prime \prime} \mathrm{N}$ and Longitude $\left.087^{0} 14.4^{\prime} 48.5^{\prime \prime} \mathrm{E}\right), \quad$ Dudhfarm (Latitude $26^{\circ} 29^{\prime} 57.6^{\prime} \mathrm{N}$ and Longitude $087^{\circ} 16^{\prime} 44.5^{\prime \prime} \mathrm{E}$ ) and Old airport (Latitude $26^{0} 25^{\prime} 40.8^{\prime} \mathrm{N}$ Longitude $087^{0} 16^{\prime} 34.3$ 'E) were surveyed and identified, then absolute counting was carried out at $8 \mathrm{AM}$ to $10 \mathrm{AM}$ in the same time in all sites. Birds were counted using point surveys within radius of $50 \mathrm{~m}$. Five point counts were done along transect at $0 \mathrm{~m}, 100 \mathrm{~m} 200 \mathrm{~m}, 300 \mathrm{~m}, 400 \mathrm{~m}$ and $500 \mathrm{~m}$. This was repeated for each site. Anthropogenic impacts were studied by means of direct observation. The effect of human activities on birds was noted visiting study sites. Birds were counted in the study sites seasonally following the point count method designed by Bibby et al. (1992)

Ten years weather report of mainly of Biratnagar was taken from the Department of Hydrology and Meteorology, Dharan and comparative study was done.Climate change has been most pronounced global problem which is prevalent in Nepal too. Birds are most responsive to the climate change.

Interviews, with local people were taken about the impact of climate change on birds. Data analysis was done using Ms excel software to calculate Shannon Wiener diversity index, to draw bar diagram, pie chart and temperature graph. Secondary data was collected through the review of published and unpublished documents, reports etc. important and pertinent facts and figures were also retrieved from the internet.

\section{Results}

\section{Population Status}

Altogether eighty one species of birds belonging to thirty three families were recorded. Among them Muscicapidae, showed the highest number of species representatives (eight) followed by Cuculidae, Corvidae, and Passeridae with five representatives each. Similarly Colubridae, Ardeidae, Scolopidae, Sturnidae stood in the third position each represented by four species. Alcedinidae, and Accipitridae were represented by three species. Hirunidae, Phalacrocoracidae, Laniidae, Psittacidae, Emberizidae, Ciconidae and Charadriidae were represented by two species. Rhalidae, Strigidae, Centropodidae, Magalaimidae, Picidae, Alaudidae, Oriolidae, Apopoidae, Coraciidae, Upupidae, Nectarinidae, Threskornithidae and Anatidae were represented by least number of representatives (Table $1)$.

One year regular observation of birds of Biratnagar showed their highest number in winter season and lowest in Monsoon (fig.1) and status $59.23 \%$, fairly common, $28.38 \%$ common and $12.34 \%$ uncommon 
Kanchan Jha and Bharat Raj Subba / Our Nature (2012) 10: 24-33

Table 1. Checklist of Birds

\begin{tabular}{|c|c|c|c|c|c|c|}
\hline SN & FAMILY & SCIENTIFIC NAME & COMMON NAME & NEPALI NAME & STATUS & REMARK \\
\hline 1 & Rhalidae & Amaurornis phoenicurus & $\begin{array}{l}\text { White- breasted } \\
\text { Waterhen }\end{array}$ & सिमकुखुरा & $\mathrm{R}$ & $\mathrm{C}$ \\
\hline \multirow[t]{6}{*}{2} & Corvidae & & & & & \\
\hline & & Corvus splendens & House Crow & घर काग & $\mathrm{R}$ & $\mathrm{FC}$ \\
\hline & & Dendrocitta vagabunda & RufousTreepie & कोकले & $\mathrm{R}$ & $\mathrm{C}$ \\
\hline & & Corvus macrorhynchos & Jungle Crow & कलो काग & $\mathrm{R}$ & $\mathrm{FC}$ \\
\hline & & Dicrurus macrocerus & Black Drongo & कला चिबे & $\mathrm{R}$ & $\mathrm{FC}$ \\
\hline & & Aegithina tiphia & Common Iora & ससेली चरी & $\mathrm{R}$ & $\mathrm{C}$ \\
\hline \multirow[t]{5}{*}{3} & Columbidae & & & & & \\
\hline & & Streptopelia chinensis & Spotted Dove & कर्ले ढुकुर & $\mathrm{R}$ & $\mathrm{FC}$ \\
\hline & & Columba livia & Pigeon & मलेवा & $\mathrm{R}$ & $\mathrm{FC}$ \\
\hline & & Streptopelia decaoto & Indian Ring Dove & कण्ठे ढुकुर & $\mathrm{R}$ & $\mathrm{FC}$ \\
\hline & & Streptopelia tranquebarica & Red-Collared Dove & सानोतामे ढुकुर & $\mathrm{R}$ & $\mathrm{C}$ \\
\hline \multirow[t]{3}{*}{4} & Pycnonotidae & & & & & \\
\hline & & Pycnonotus cafer & Red -vented Bulbul & जुरेली & $\mathrm{R}$ & $\mathrm{FC}$ \\
\hline & & Pycnonotus jacosus & Red- whiskered Bulbul & l|linhl|l. & $\mathrm{R}$ & FC \\
\hline \multirow[t]{3}{*}{5} & Laniidae & & & & & \\
\hline & & Lanius cristatus & Brown Shrike & WhItedot & W V & $\mathrm{C}$ \\
\hline & & Lanius schach & Long- tailed Shrike & eb101 & W V & $\mathrm{C}$ \\
\hline \multirow[t]{5}{*}{6} & Sturnidae & & & & & \\
\hline & & Acridotheres tristis & Common Myna & 8!? & $\mathrm{R}$ & $\mathrm{FC}$ \\
\hline & & Sturnus contra & Pied Myna & $8+4 \mid: t / H$ & $\mathrm{R}$ & $\mathrm{FC}$ \\
\hline & & Acridotheres ginginianus & Bank Myna & d.7 Ik! & $\mathrm{R}$ & FC \\
\hline & & Sturnus malabaricus & Grey- headed Myna & Vlllotps l?k. & $\mathrm{R}$ & $\mathrm{C}$ \\
\hline \multirow[t]{5}{*}{7} & Ardeidae & & & & & \\
\hline & & Bubulcus ibis & Cattle Egret & fat as $\| n \mid$ & $\mathrm{R}$ & $\mathrm{FC}$ \\
\hline & & Ardeola grayii & Indian Pond Heron & ci;sth|as $\| n\}$ & $\mathrm{R}$ & $\mathrm{FC}$ \\
\hline & & Mesophoyx intermedia & Intermediate Egret & dentilitas $\ln$ & $\mathrm{R}$ & $\mathrm{C}$ \\
\hline & & Nycticorax nycticorax & $\begin{array}{c}\text { Black-crowned Night } \\
\text { Heron }\end{array}$ & ais $\mid a s \| n i$ & $\mathrm{R}$ & $\mathrm{C}$ \\
\hline \multirow[t]{9}{*}{8} & Muscicapidae & & & & & \\
\hline & & Rhipidura albicollis & $\begin{array}{l}\text { White- throated fantail } \\
\text { Flycatcher }\end{array}$ & Nifins $07 \mid$ onds & $\mathrm{R}$ & $\mathrm{C}$ \\
\hline & & Culicicapa ceylonesis & $\begin{array}{l}\text { Grey- headed } \\
\text { Flycatcher }\end{array}$ & $R+1 \cap|G| h \mid s$ & W V & $\mathrm{C}$ \\
\hline & & Ficedula parva & $\begin{array}{l}\text { Red- throated } \\
\text { Flycatcher }\end{array}$ & Nitins s7ing is & W V & $\mathrm{C}$ \\
\hline & & Phoenicurus ochuros & Black Redstart & Ho iks $!(\cdot n / !$ & $\mathrm{R}$ & $\mathrm{C}$ \\
\hline & & Luscinia pectoralis & $\begin{array}{l}\text { White-tailed } \\
\text { Rubythroat }\end{array}$ & Ixd in L I it if 07 & $\mathrm{R}$ & $\mathrm{C}$ \\
\hline & & Saxicola torquata & Collard Bushchat & 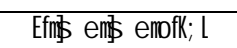 & WM & $\mathrm{C}$ \\
\hline & & Turdus ruficollis & Dark-throated Thrush & $s \ln \operatorname{ls} 07 R \operatorname{lif} \mid$ & WV & $\mathrm{UC}$ \\
\hline & & Saxicoloides fulicata & Indian Robin & Wifl| g. I |f & $\mathrm{R}$ & FC \\
\hline \multirow[t]{2}{*}{9} & Cuculidae & & & & & \\
\hline & & Eudynamys scolopacea & & $s \operatorname{lon} 1$ & $\mathrm{R}$ & $\mathrm{FC}$ \\
\hline
\end{tabular}


Kanchan Jha and Bharat Raj Subba / Our Nature (2012) 10: 24-33

\begin{tabular}{|c|c|c|c|c|c|c|}
\hline & & & Asian Koel & & & \\
\hline & & Clamator jacobinus & Pied- crested Cuckoo & $k m\} \mid \operatorname{lon}$ & $\mathrm{SV}$ & $\mathrm{C}$ \\
\hline & & Cuculus canorus & Eurasian Cuckoo & ssssilnat & SV & $\mathrm{C}$ \\
\hline & & Cuculus micropterus & Indian Cuckoo & s fik mo kiso it & SV & $\mathrm{C}$ \\
\hline & & Hierococcyx varius & $\begin{array}{c}\text { Common Hawk } \\
\text { Cuckoo }\end{array}$ & $2 \ln S \mid \times 0 i$ & $\mathrm{SV}$ & $\mathrm{C}$ \\
\hline 10 & Centropodidae & Centropus sinensis & Great Coucal & $918 \mid \| 1\} 1$ & $\mathrm{R}$ & $\mathrm{FC}$ \\
\hline \multirow[t]{4}{*}{11} & Alcedinidae & & & & & \\
\hline & & Halcyon smyrnensis & $\begin{array}{c}\text { White- throated } \\
\text { Kingfisher }\end{array}$ & $S \mid 1$ & $\mathrm{R}$ & $\mathrm{C}$ \\
\hline & & Ceryle rudis & Pied kingfisher & $\sin 1 / \operatorname{lo} \mid 0$ ix it & $\mathrm{R}$ & $\mathrm{UC}$ \\
\hline & & Halcyon capensis & $\begin{array}{c}\text { Stork- billed King } \\
\text { fisher }\end{array}$ & $\ln 11016 ! s \| 1$ & SV & $\mathrm{UC}$ \\
\hline \multirow[t]{2}{*}{12} & Megalaimidae & & & & & \\
\hline & & Megalaima asiatica & Blue- throated Barbet & 5131 & $\mathrm{R}$ & $\mathrm{C}$ \\
\hline \multirow[t]{2}{*}{13} & Picidae & & & & & \\
\hline & & Dinopium benghalense & $\begin{array}{c}\text { Lesser golden -backed } \\
\text { Woodpecker }\end{array}$ & $\sin i f|l| n|x| t$ & $\mathrm{R}$ & $\mathrm{C}$ \\
\hline \multirow[t]{4}{*}{14} & Accipitridae & & & & & \\
\hline & & Accipiter niscus & $\begin{array}{c}\text { Eurasian Sparrow } \\
\text { hawk } \\
\end{array}$ & gath & W V & $\mathrm{C}$ \\
\hline & & Haliaeetus leucoryphus & Pallas's Fish Eagle & Aits; LII I & WV & $\mathrm{UC}$ \\
\hline & & Milvus migrans & Black Kite & $\sin 4 \| \operatorname{lin}$ & WV & $\mathrm{UC}$ \\
\hline \multirow[t]{2}{*}{15} & Alaudidae & & & & & \\
\hline & & Mirafra assamica & $\begin{array}{l}\text { Rufous-winged } \\
\text { Bushlark }\end{array}$ & : itilifith & WV & $\mathrm{C}$ \\
\hline \multirow[t]{2}{*}{16} & Oriolidae & & & & & \\
\hline & & Oriolus xanthornus & Black- hooded Oriole & sinfloipsligill & $\mathrm{R}$ & $\mathrm{C}$ \\
\hline \multirow[t]{7}{*}{17} & Passeridae & & & & & \\
\hline & & Anthus rufulus & Paddyfield Pipit & $6 \operatorname{lng} 10014$ & $\mathrm{R}$ & $\mathrm{C}$ \\
\hline & & Motacilla alba ducunensis & $\begin{array}{c}\text { Grey- headed } \\
\text { Wagtail(black backed } \\
\text { form) }\end{array}$ & $i 1116 s|6 s|$ & $\mathrm{R}$ & $\mathrm{C}$ \\
\hline & & Motacilla cinerea & $\begin{array}{c}\text { Pied Wagtail (Grey } \\
\text { backed form) }\end{array}$ & $k m_{1}^{\prime}$ IIlos lbs & $\mathrm{R}$ & $\mathrm{C}$ \\
\hline & & Passer domesticus & House Sparrow & $3 \mid e+1$ & $\mathrm{R}$ & $\mathrm{FC}$ \\
\hline & & Motacilla maderaspatensis & $\begin{array}{c}\text { White- browed } \\
\text { Wagtail }\end{array}$ & VIfn los los & $\mathrm{R}$ & $\mathrm{C}$ \\
\hline & & Lonchura punctulata & Scaly-breasted Munia & $s \| f|f| d \lg 0=t$ & $\mathrm{R}$ & $\mathrm{C}$ \\
\hline \multirow[t]{3}{*}{18} & Phalcrocoracidae & & & & & \\
\hline & & Phalacrocorax niger & Little Cormorant & $i \lg \mid \ln \| 1$ & $\mathrm{R}$ & $\mathrm{UC}$ \\
\hline & & Phalacrocorax carbo & Great Cormorant & 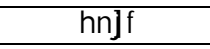 & $\mathrm{R}$ & $\mathrm{UC}$ \\
\hline \multirow[t]{2}{*}{19} & Apodidae & & & & & \\
\hline & & Cypriurus balasiensis & Asian Palm Swift & Yis 1 vil| 1 & $\mathrm{R}$ & $\mathrm{C}$ \\
\hline \multirow[t]{3}{*}{20} & Charadriidae & & & & & \\
\hline & & Vanellus indicus & Red-wattled Lapwing & $\times 166019$ & $\mathrm{R}$ & $\mathrm{C}$ \\
\hline & & Rostratula benghalensis & Greater Painted-snipe & Xith 1 ixi & $\mathrm{R}$ & $\mathrm{C}$ \\
\hline
\end{tabular}


Kanchan Jha and Bharat Raj Subba / Our Nature (2012) 10: 24-33

\begin{tabular}{|c|c|c|c|c|c|c|}
\hline 21 & Meropidae & & & & & \\
\hline & & Merops orientalis & Green Bee-eater & $\ln |n| i$ & W V & $\mathrm{C}$ \\
\hline & & Merops philippinus & Blue-tailed Bee- eater & $\ln (\operatorname{kg}|0| \ln \mid i$ & WV & $\mathrm{C}$ \\
\hline \multirow[t]{3}{*}{22} & Hirundinidae & & & & & \\
\hline & & Riparia riparia & Sand Martin & Vin xll le Q U If $n$ L & $\mathrm{R}$ & $\mathrm{C}$ \\
\hline & & Delichon nipalensis & Nepal House Martin & 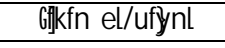 & $\mathrm{R}$ & $\mathrm{C}$ \\
\hline \multirow[t]{5}{*}{23} & Scolopacidae & & & & & \\
\hline & & Calidris minuta & Little Stint & $\sin \ln \int \mid h \cap \|$ & WV & $\mathrm{C}$ \\
\hline & & Calidris temminckii & Temminck's Stint & hin II & WV & $\mathrm{C}$ \\
\hline & & Tringa terek & Terreck Sandpiper & 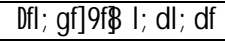 & WV & $\mathrm{C}$ \\
\hline & & Actitis hypoleucos & Common Sandpiper & $R i \times 101: 811801$ & WV & $\mathrm{C}$ \\
\hline \multirow[t]{2}{*}{24} & Coraciidae & & & & & \\
\hline & & Coracias benghalensis & Indian Roller & 1611 & $\mathrm{R}$ & $\mathrm{UC}$ \\
\hline \multirow[t]{2}{*}{25} & Upupidae & & & & & \\
\hline & & Uрира ерорs & Hoopoe & $k|k| 11$ & $\mathrm{R}$ & $\mathrm{C}$ \\
\hline \multirow[t]{3}{*}{26} & Psittacidae & & & & & \\
\hline & & Psittacula himalayana & Slaty-headed Parakeet & Dibgitit & $\mathrm{R}$ & $\mathrm{UC}$ \\
\hline & & Psittacula krameri & Rose-ringed Parakeet & s01!ivi & $\mathrm{R}$ & $\mathrm{UC}$ \\
\hline \multirow[t]{2}{*}{27} & Nectariniidae & & & & & \\
\hline & & Nectarinia asiatica & Purple Sunbird & $\sin 1 j:|1| i$ & $\mathrm{R}$ & FC \\
\hline \multirow[t]{5}{*}{28} & Sylviidae & & & & & \\
\hline & & Phylloscopus fuscatus & Dusky Warbler & 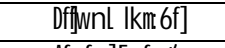 & W V & $\mathrm{C}$ \\
\hline & & Turdoides striatus & Jungle Babbler & Afu in $\mid$ io is | & $\mathrm{R}$ & FC \\
\hline & & Orthotomus suctorius & Common Tailor bird & 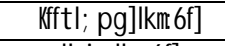 & $\mathrm{R}$ & $\mathrm{FC}$ \\
\hline & & Phylloscopus trochiloides & Greenish Warbler & $\ln |\mathrm{n}| \mathrm{km}: 6 \mathrm{il}$ & W V & $\mathrm{C}$ \\
\hline \multirow[t]{2}{*}{29} & Therskiornithidae & & & & & \\
\hline & & Pseudibis papillosa & Black Ibis & 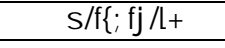 & $\mathrm{R}$ & $\mathrm{C}$ \\
\hline \multirow[t]{3}{*}{30} & Ciconiidae & & & & & \\
\hline & & Anastomus oscitans & Asian Openbill & 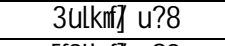 & $\mathrm{R}$ & $\mathrm{FC}$ \\
\hline & & Leptoptilos javanicus & Lesser Adjustant & :58 kk mí $\cup 18$ & $\mathrm{R}$ & FC \\
\hline \multirow[t]{2}{*}{31} & Anatidae & & & & & \\
\hline & & Dendrocygna javanica & Lesser Wistling- teal & $|; n| ; n \mid$ & $\mathrm{R}$ & FC \\
\hline 32 & Strigidae & Bubo coromandus & Dusky-horned Owl & [it; it s & $\mathrm{R}$ & $\mathrm{C}$ \\
\hline \multirow[t]{3}{*}{33} & Emberizidae & & & & & $\mathrm{C}$ \\
\hline & & Emberiza aureola & $\begin{array}{c}\text { Yellow-breasted } \\
\text { Bunting }\end{array}$ & 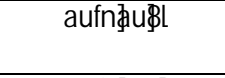 & WV & \\
\hline & & Emberiza melanocephala & Grey-headed Bunting & Sigsilaull. & WV & $\mathrm{C}$ \\
\hline
\end{tabular}

$\mathrm{R}=$ Resident, WV=Winter Visitor, $\mathrm{SV}=$ Summer Visitor, $\mathrm{C}=$ Common, $\mathrm{FC}=$ Fairly Common, UC=Uncommon

(fig2). Thus uncommon species are very few in number. Among 81 species of birds recorded are $69.10 \%$ resident, $25.91 \%$ winter visitor and $4.93 \%$ summer visitor (fig.3).

The habitats of birds are different according to their feeding, roosting and nesting habits. Bird habitat depends on where they feed or roost or make their nest. Most of the birds are selective in their choice of breeding sites and may even be restricted to a shortage of nest sites. Because of rapid replacement of paddy field and marshy lands for human settlement and industries establishment within nearly one and half decade nearly seventy percent of 
Kanchan Jha and Bharat Raj Subba / Our Nature (2012) 10: 24-33

bird habitat in Biratnagar has been exploited.

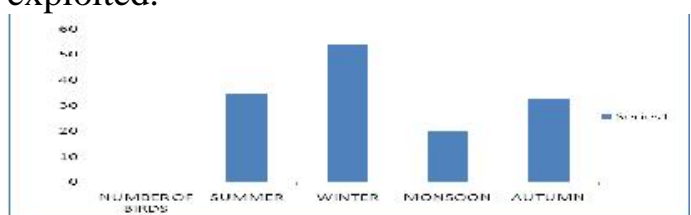

Figure 1. Bar diagram showing species of bird in different season

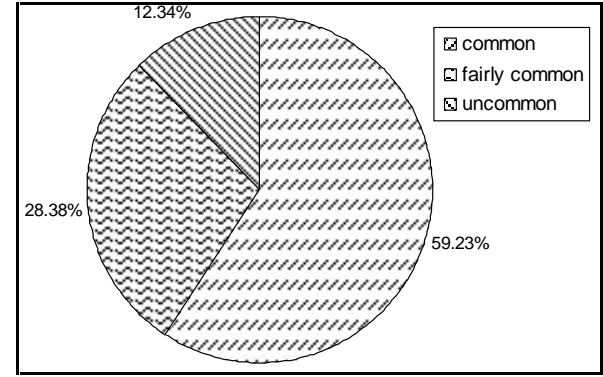

Figure 2. Population status of bird

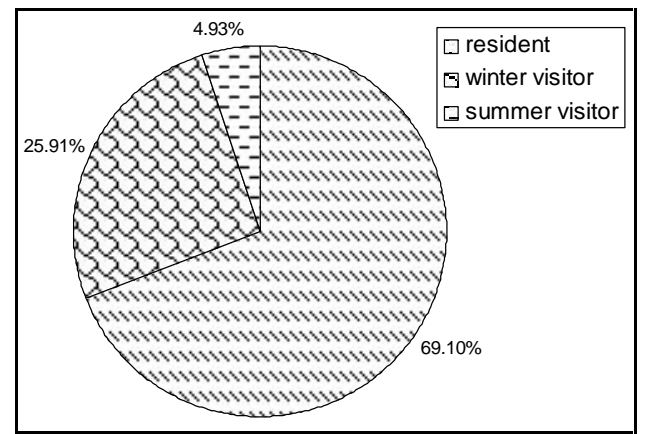

Figure 3. Behaviors of bird.

In the present study birds living at different habitats such as tree, shrub, wetland and meadow were found. Number of species of bird living on tree was higher than that of shrub, followed by wetland habitat, tree and bush and least number of species were found living in both tree and land given by $27.14 \%, 20.97 \%, 28.38 \%$, $9.87 \%$ and $13.57 \%$ respectively (Fig.4).The Shannon Wiener diversity index in summer and winter were found to be 3.68361 and 4.1328 respectively

\section{Anthropogenic Impacts}

Bird's population was found severely affected by anthropogenic impact in Biratnagar. This decline of species is cause of natural and anthropogenic factor. Natural factor include climate change, drought, flood, global warming and anthropogenic factor include habitat loss, wetland loss, poaching, loss of feeding ground, excessive use of insecticide, agriculture pattern, land use pattern, lack of awareness about its importance.

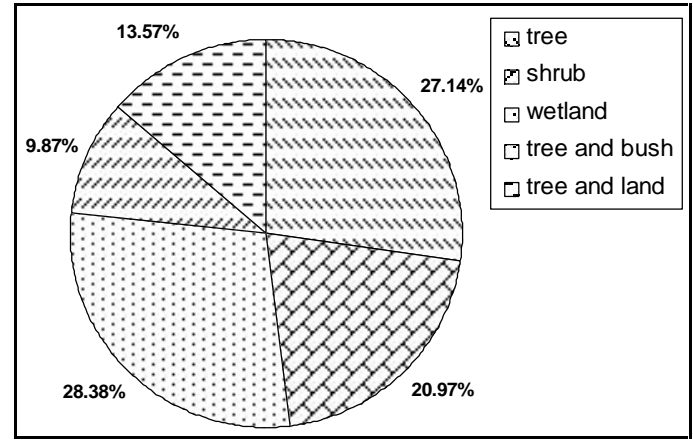

Figure 4. Showing different habitat of bird

\section{Habitat loss}

The bulging population size in the cities has been replacing birds in varied ways. Most of the wetland has been encroached by human for different purposes such as agriculture, human settlement, by establishing industries etc. Wetland loss has greatly affected to wetland birds. To feed growing population and give them shelter nothing could be done besides making encroachment of bird's habitats.

\section{Urbanization}

In Biratnagar immigration is increasing day by day. People especially from Siraha, Saptari, and Dhanusha are migrating here either for better job or quality education or better facilities or for security purpose. This has increased land plotting business where 
Kanchan Jha and Bharat Raj Subba / Our Nature (2012) 10: 24-33

landowner sells lands at high prices. We can see no single place left untouched, on both sides of highway or sub-road. Farmers sell their cultivable land for housing purpose. Trees are fallen down so that more land can be made to sell. Even banks of river like Keshalia khola and Singhia khola have almost been occupied by houses and mills.

\section{Poaching}

Biratnagar sub- metropolis is still behind to increase literacy rate and provide knowledge about conservation of wildlife. Poaching is the main problem for birds in this Sub-Metropolis city. Selling of buntings, whistling teal for meat in early winter morning and birds like sparrow and parakeet for ornamental purpose in the market areas can be witnessed Chidimars and Batars hunting White -breasted Waterhen, Sparrow, and Cattle Egret are also killed for meat.

\section{Use of insecticide}

Nepal is an agricultural country. Still more than $90 \%$ people are dependent on agriculture. The use of pesticides in agriculture, garden, orchard has been common in Biratnagar. This sort of practice is detrimental not only to insects and other pests but it is harmful to birds as well. Use of pain killer drug dichlofenac had been most dangerous means to wipe out population once until the causative agent had not been identified.

\section{Land use system}

Most of the cultivable fields are being plotted for housing purpose. Farmers sell their agricultural field in high price. Land is left unfarmed. Riverside of Keshalia khola and Singhia khola are even covered by houses. Small patches of greeneries are also decreasing day by day. The species of bird which prefer to remain in cultivated lands are facing the habitat problem. They barren or uncultivated lands are used for cattle grazing purpose so that sorts of land are unsafe for foresaid birds. In the same time grain eating birds also suffer from shortage of food, if agricultural lands are not cultivated. Cultivated land provides birds both shelter and food.

\section{Impact of Climate Change}

The metrological data of 1970, 2004, 2007 and 2011 of Biratnagar have depicted that climate has been changing. There have occurred some notable changes in the pattern of temperature, humidity, and rainfall. The alternation in humidity, temperature and rainfall has been shown (Fig5, 6, 7). Birds are most sensitive to climate change. Among bird species which can cope with gradual change in temperature are still showing normal behavior but sensitive ones have already left their original habitat.

\section{Feeding Behavior}

Feeding behavior of birds depend on various environmental factors such as geographical location habitats, season, water quality, competition (intraspecific and interspecific) and scarcity of food etc. Due to scarcity of food and drastic alteration in environment, many birds have been found adopting alternate food like Cattle Egret, Green Beeeater, Common Myna, Bank Myna, Indian Treepie, Red- vented Bulbul, Magpie Robin, Drongo, Jungle Babbler, Pied- crested Cuckoo, Kingfisher, Flycatcher, Owl, Jungle Crow etc.

The feeding habit of birds recorded during study time in Biratnagar are carnivore $28.38 \%$, omnivore $14.80 \%$ insec- 
Kanchan Jha and Bharat Raj Subba / Our Nature (2012) 10: 24-33

tivore $40.72 \%$, fructivore $3.70 \%$, grainivore $11.70 \%$ and nectivore 1.23 (fig. 8 )

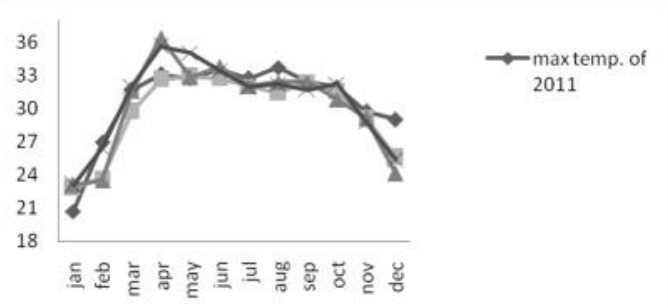

Figure 5. Graphical representation of maximum Temperature of Biratnagar of year (2O11, 2007, 2004 and1970 (Source: Dept. of Hydrology and Meteorology 2011).

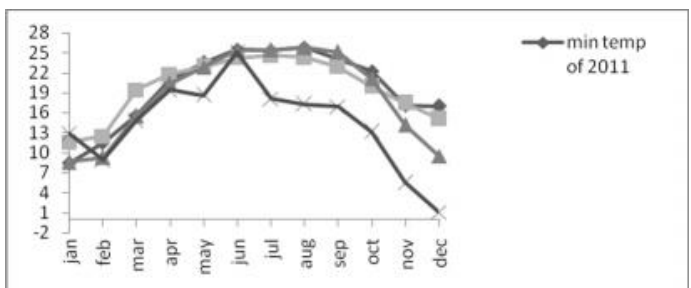

Figure 6. Graphical representation of minimum Temperature of Biratnagar of year (2O11, 2007, 2004 and1970) (Source: Dept. of Hydrology and Meteorology 2011).

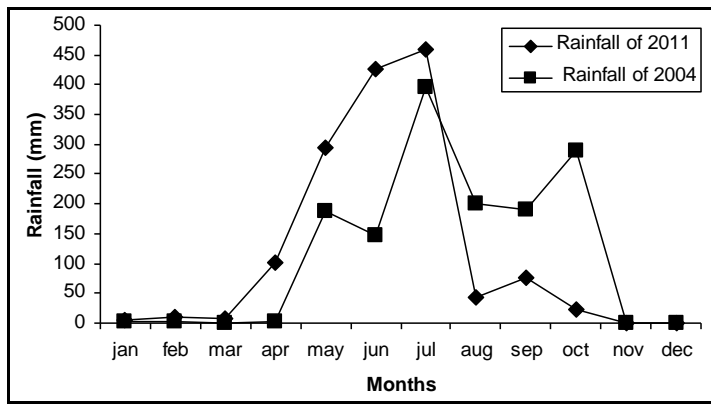

Checklist of birds of Biratnagar Subba(1994)depicts 93 species belonging to 39 families. It is clear that bird species

Figure 7. Graphical representation of rainfall of Biratnagar of year (2O11 and 2004) (Source: Dept. of hydrology and Meteorology 2011)

\section{Discussion}

belonging to 6 families ie, $15.38 \%$ did not turnout during survey.

The impact of weather on population biology of birds has been a major field of study for ornithologists over the past half century. Weather not only affect metabolic rate of birds but it also has other indirect and direct affect on birds behavior for example it can influence foraging condition and ability to carry out other essential behavior such as courtship. Weather also impacts on breeding succession through for example chilling or starvation of young. There are many negative impacts on bird due to climate change such as earlier breeding changes at the timing of migration, survey of one year's duration in eightyone species belonging to thirtythree families. changes in breeding performance, changes years. The recorded bird species in present in population sizes, changes in selection differential between components of population Stevenson et al. (2000). Birds are very special targets to climate change wise. The most remarkable finding in

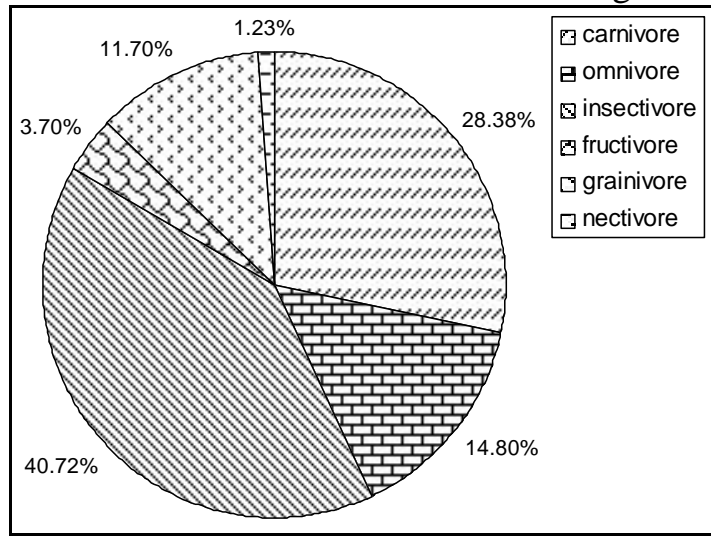

Figure 8. Feeding habitat of bird.

The population of birds in Biratnagar has been found due to have decreased species declination of bird species within eighteen impacts for many reasons Sparks et al. (2002). They are homoeothermic animals 
living actively year round except some birds species which are not available in Biratnagar. They live very exposal lives. Many bird species change their living area twice a year over a several climate and vegetation zones. This large scale connectivity between summer and winter phase is a peculiarity special almost only to birds.

They have several separate phases in their annual cycle, which have to adapt to variable changes of both climatic and living are simultaneously, optimizing the net response breeding, molt, autumn migration, wintering, and spring migration of birds. Also breeding times have responded to climate change. Much less is known about other phases of annual cycle and although there are several care of suggested changes of distribution ranges, rigid analysis that take into account other possible causes and also separate direct and indirect impacts of climate change from each other to be waited. The impact of climate change on Nepalese bird is currently poorly understood, but is likely to be significant (Baral and Inskipp, 2004). Biratnagar is not an exceptional place from the global impact of climate change. The comparative study of meteorological data of (1970, 2004, 2007 and 2011) presented clearly depict that climate has changed and the change climate has changed environment too. In winter it is excessive cold and summer is very hot. It doesn't rain on time and the soil is drying up. So productivity is decreasing. Thrushes which were recorded in 1996 did not turn out in winter.

The feeding habit of bird has been highly affected by the urbanization and industrialization of this sub metropolis city. Effects of residential development on forestdwelling neotropical migrant songbirds
Friensen et al. (1995). The worldwide urbanization has great impact on birds Marzluff et al. (2001). The bird feeding ground of grainivores like Indian tree pie, parakeets, dove, buntings has greatly affected because of decrease in agricultural land. They don't find enough grain to feed as transformation of agricultural land into concrete land has taken place. Interest in agriculture is decreasing in urban people. New generation is rarely seen getting involved in this field. This has affected the grainivores, nectivores and fructivores. We can see green areas in few regions of Biratnagar where birds can enjoy their feeding and nestling habitat. Most of flowering plants and fruits bearing plants are chemical sprayed, which affect fructivores, nectivores and insectivores being slow poison, decrease either their fertility rate or get deposited heavy metals in their kidney, liver and muscles and shorten their life span. The chemicals sprayed have greatly affected the breeding habitat of birds of Biratnagar. The polluted water of river affects the organism living in it. The decrease in aquatic organism has direct impact on wetland bird such as Storkbilled Kingfisher, Cormorant, Snipe, Sandpiper; Black Ibis Asian Openbill, Lesser Adjutant, Pallas's Fish Eagle and many more.

Up to three decade back, in Biratnagar, bird's habitats were almost safe. Here one could observe more than fifty species of birds in two hours bird watching in any season. Subba (1994) recorded 93 species of bird in same locality and the time this year only 81 species were recorded on regular observations. Many species like Leptoptilos dubius, Cicona episcopus, Gypus indicus , Gyps fulvus,Milvus migrans(only once), Circus melanoleucos, Charadrius dubius, 
Kanchan Jha and Bharat Raj Subba / Our Nature (2012) 10: 24-33

Tringa nebularia, Burhinus oedicnemus, Capella gallinago, Athene brama, Apus affinis(only once in few number). Alcedo meninting, Megalaima haemacephala, Dendrocopus nanus, Pitta indica did not turn out this time. This is due to either habitat shrinkage or anthropogenic impacts or may be because of both reasons and climate change. Within one decade urbanization has touched the peak here. Marshy lands have been encroached almost completely. Fernandez et al.(2000) has revealed about the local and regional effects of pedestrians on forest birds in fragmental landscape. River waters have become polluted and are not suitable for wetland birds. People are really apathy for the conservation of bird habitat and there nesting and feeding sites. The population of each and every species of bird has been declining remarkably. If birds safeguard activities will not be made popular in time and made people realize why birds have to be protected and conserved, there lies every possibility of declining birds population as well as species in near future. If conservation of birds will remain restricted to slogan only then time may come when it will be too late for safeguard of birds.

\section{Acknowledgements}

The first author is grateful to NAST, Nepal for the financial support to carry out the research. The authors are also thankful to Department of Hydrology and Meteorology, Dharan for providing meteorological data.

\section{References}

Baral,H.S.and S.S.Inskipp 2001. Important Birds areas in Nepal: A report to the Royal Society for the protection of birds, U.K Kathmandu: Bird Consevation Nepal.

Baral,H.S. and C. Inskipp 2004. The state of Nepal's bird 2004.Deparment of National park and
Wildlife Conservaion, Bird Conservation Nepal and IUCN Nepal, Kathmandu.

Bibby,C.,B.N. Burges and D.A.Hill1992. Birds census techniques.Academic press, London.

Fernandez-Juricic, E. 2000. Local and regional effects of pedestrians on forest birds in fragmental landscape. Condor 102:247-255.

Flemming Sr. R.L., R.L. Flemming Jr. and L.S Bandel 1984.Birds of Nepal. Nature Himalayas, Kathmandu, Nepal.

Friensen, L.E.,P.F.J.Eagles and R.J. Mackay 1995. Effects of residential development on forestdwelling neotropical migrant songbirds. Conservation Biology 9:1408-1414.

Jha,K. and B.R.Subba 2011. Studies on birds of Biratnagar Sub- Metropolis, Nepal. Nepalese Journal of Bioscience. 1:37-40

Jha,K. and B.R. Subba 2012. Impacts of climate change on Birds of Biratnagar, Nepal. Nepalese Journal of Bioscience. 2:158-159

Marzluff, J.M., R. Bowman and R. Donnelly 2001. Worldwide urbanization and its effects on birds.Avian ecology and conservation in an urbanizing world. Kluwer a academic publishers. Boston, Massachusetts,USA .S19-45

Mechi to Mahakali.edition I, 1974.

Shrestha, T.K.2001.Birds of Nepal.Kathmandu, Nepal.

Sparks, T.H., H.Q.P.Crick,N.Elkins, S.Moss,and K. Mylne 2002. Birds, weather and climate.Weather57:399-410.

Stevenson I.R. and D.M.Bryant 2000.Climate change and constraints on breeding.Nature 406:366-367.

Subba, B.R.1994.Checklist of Birds of Biratnagar, News letter for Birdwatchers.Published biomonthly by Sridhar at Navbharath Enterprises, Sesadripuram, Bangalore 560 020. India, 34 (6): $128-129$

Subba, B.R.1995. Checklistof Birds of Dharan, News letter for Birdwatchers .Published biomonthly by Sridhar at Navbharath Enterprises, Sesadripuram, Bangalore 560 020. India,34 (4):115-116.

Subba, B.R. 1997. Checklist of Birds of Gajurmukhi V.C.D. of Ilam, Vishaleshan Vol.2:20-23.

Subba, B.R. 2001. Garden Birds, INFO Science the first Scientific Publication from Biratnagar.

Subba, B.R. 2004. Different ways of bird conservation .Eastern Mirror.Nov.Dec.

Surana,R.,B.R.Subba,and K.P. Limbu 2007.Avifauna Diversity during rehabilitation stage of Chimdi lake, Sunsari,Nepal. Our Nature. 5:75-80. 